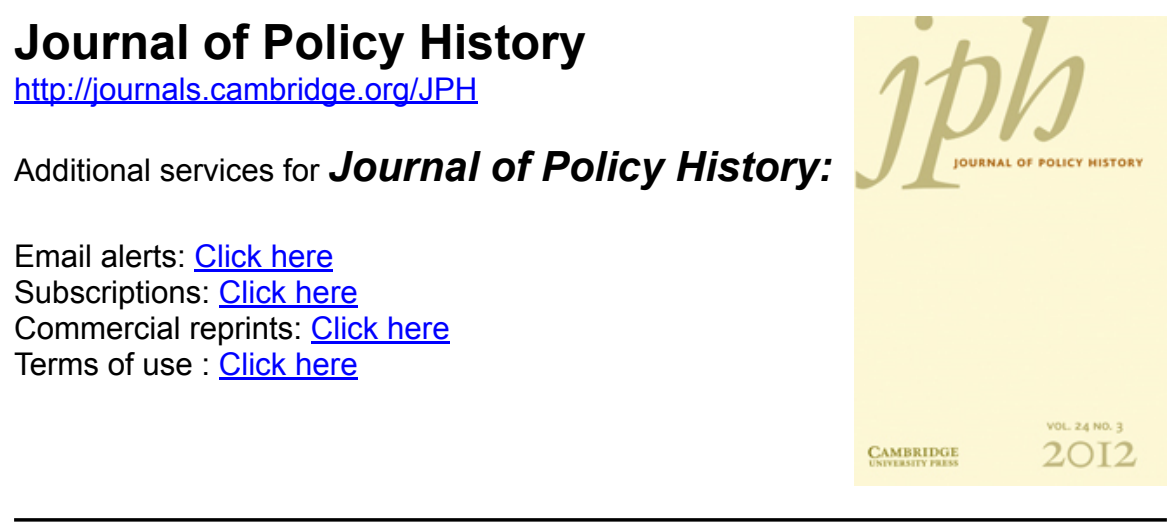

\title{
Toward a New Welfare History
}

\author{
Stephen Pimpare \\ Journal of Policy History / Volume 19 / Issue 02 / April 2007, pp 234 - 252 \\ DOI: 10.1353/jph.2007.0012, Published online: 27 April 2009 \\ Link to this article: http://journals.cambridge.org/abstract S0898030600001640 \\ How to cite this article: \\ Stephen Pimpare (2007). Toward a New Welfare History. Journal of Policy \\ History,19, pp 234-252 doi:10.1353/jph.2007.0012 \\ Request Permissions : $\underline{\text { Click here }}$
}




\section{STEPHEN PIMPARE}

\section{Toward a New Welfare History}

Histories of American welfare have been stories about the state. Like Walter Trattner's widely read From Poor Law to Welfare State, now in its sixth edition, they have offered a narrative about the slow but steady expansion and elaboration of state and federal protections granted to poor and working people, and have usually done so by charting increases in government expenditures, by documenting the institutionalization of welfare bureaucracies, and by tracing rises or declines in poverty, unemployment, and other aggregate measures of well-being. ${ }^{1}$ This has been the case even in more critical accounts that emphasize that American social welfare history is not a story just of progress, such as Michael Katz's In the Shadow of the Poorhouse. ${ }^{2}$ These narratives have emphasized programs, not people (whether it is the poorhouse, the asylum, and mother's pensions, or the more recent innovations of national unemployment insurance, Social Security, AFDC and TANF, and Medicare and Medicaid). In the investigations of the welfare state that dominate academic research, the content and timing of government policy itself has served as the dependent variable, while the independent variables have been a congeries of interests, institutions, and policy entrepreneurs. Our attention has been focused upon what government has done, why it was done, and what the effects were as measured in official data.

Recent scholarship has thereby brought us new understandings of the patronage powers that led to the expansion of pensions to Civil War veterans, ${ }^{3}$ evaluated the influence of organized business interests during debate over the Social Security Act of $1935^{4}$ and in other eras, ${ }^{5}$ shown

Previous versions of this article were presented at the New York Colloquium on American Political Development and the Social Science History Association. My thanks for the many helpful comments and critiques received there, and from Richard Caputo, Sanford Schram, and the Journal's review.

THE JOURNAL OF POLICY HISTORY, Vol. 19, No. 2, 2007.

Copyright (C) 2007 The Pennsylvania State University, University Park, PA. 
how the Democratic South shaped welfare policy to its racist and economic ends, ${ }^{6}$ explained the impetus behind the recent repeal of AFDC, ${ }^{7}$ or sought to explain the repeated failures to enact guaranteed income or universal health-care programs in light of organized pressure and institutional constraints. ${ }^{8}$ When such scholarship has honed in on individual-level experience, the emphasis has been on how reformers, politicians, and bureaucrats have sought to improve the poor and their condition. Poor and working people themselves are something of an abstraction in these accounts, even in the best ones, and when they are present they are usually the objects of policy, and largely passive, Julian Zelizer's recent suggestion in these pages that "the tension between scholars who study elite politics and grass roots politics quickly dissipates when policy is made the center of inquiry" notwithstanding. ${ }^{9}$ Even in those still-exceptional cases in which poor people are protagonists in welfare history, like Frances Fox Piven and Richard Cloward's Regulating the Poor and Poor People's Movements, ${ }^{10}$ it is their collective action and influence on the political system that have been the main focus. While we have heard and continue to hear much about poor and working people, we have still heard little from them, and seen little from their perspective.

Curiously, it has been opponents of the welfare state who have more dependably sought to understand the poor as individuals, none more notoriously than Charles Murray, whose thought-experiment in Losing Ground about "Harold and Phyllis" and how the "perverse incentives" of welfare would cause this couple to prefer aid over work, has dominated public and political understanding of the street-level impact of policy: that is, how do relief programs alter poor people's engagement with their families and children, their neighbors, their neighborhoods, the labor market, and the state. ${ }^{11}$ Such stories, like Murray's, of an immobile, dangerous, and dependent underclass have so dominated policy discourse and popular understandings in part because there have been too few counter-narratives, too few accounts that, like Kathryn Edin and Laura Lein's Making Ends Meet, show us exactly how little a welfare check will buy and how poor women manage to survive nonetheless; like Katherine Newman's No Shame in My Game and Barbara Ehrenreich's Nickel and Dimed, which have revealed the daily exigencies of being a low-wage worker in postindustrial America; or like Joe Soss's Unwanted Claims, which documents the ways in which citizens' interaction with welfare bureaucracies affects their understandings of the state itself. ${ }^{12}$ There are other exceptions that belie my complaint-think of the stories collected by the Great Depression-era Federal Writers Project, or the slave narratives that give human dimension to institutionalized state repression. We even have increasingly complex 
portraits of the lives of poor and marginal people in colonial America. ${ }^{13}$ But as historian Gary B. Nash observed, even these works "are less successful in the difficult process of understanding how the poor experienced the authority of those attempting to control them." ${ }^{14}$

In the following pages, I make the case that we might now build more systematically upon these kinds of discrete analyses, integrate them, and construct an alternative history of the American welfare state. We could productively shift some of our attention away from policy per se (and perhaps push the state back out a bit) in order to move toward an examination of how the lived experience of poverty and of interacting with institutions that might ameliorate it has changed over the course of American history. By making that "lived experience of poverty" our dependent variable, scholars might better gauge the true impact of welfare state programs, relegating national, public policy to one among a variety of independent and intervening variables.

This may, I concede, create a "dependent variable problem" much like that which Paul Pierson fairly bemoans in comparative analyses of welfare state retrenchment: how one defines what is encompassed by the welfare state dictates what one will measure, Pierson observes, and thus variation in definitions of the welfare state may be at the root of conflicting findings about the form and extent of global retrenchment, resulting in analysts "talking past each other," and reducing our collective understanding of transformation (or lack thereof) in advanced welfare states. ${ }^{15}$ The analysis of the American welfare state that I propose adopts a dependent variable at odds with that of other analyses, and my suggestion is perhaps akin to when someone in the midst of a perfectly good political argument over a few beers wants to pause the debate in order to redefine terms. Nonetheless, a respecification of what we are trying to explain may open up fruitful new avenues of analysis and understanding.

It has in the past: Gøsta Esping-Andersen's attention to decommodification as the focal point of comparative welfare state policy analysis spawned more than a decade of productive research, and allowed a generation of researchers to finally move beyond crude expenditure-as-percentage-ofGDP-based evaluations of state activity and effectiveness. ${ }^{16}$ Feminist critiques of Andersen have offered even more complicated and nuanced frames through which we might comprehend the relative "friendliness" of welfare states. ${ }^{17}$ The dependent-variable shift I propose could help move toward the "explanatory integration" Jacob Hacker has called for and enrich the way in which we understand and evaluate the past and present American welfare state (just as it could, of course, obscure more than it illuminates and exacerbate the problem of disjointed welfare state narratives). ${ }^{18}$ 
This, then, is a preliminary effort at describing what such a history might look like and what benefit might be derived from it. In that spirit, I want to outline ten first consequences of such a revisionist project and suggest how that effort might (1) compel us to acknowledge the nationallevel bias inherent in welfare state history; (2) de-privilege the status of direct, public relief in policy analysis; (3) contest what we identify as the conventional central moments of American welfare state history; (4) return the innovation and activism of the poor and otherwise marginalized to the center of the narrative, in part by taking more seriously their evaluations of the causes of poverty and the best means toward ameliorating it; (5) require that the traditional story of welfare state progress compete with a narrative of stasis, or of regress; (6) integrate more fully analyses of poverty and welfare receipt based on life-course patterns instead of point-in-time data, expanding the universe of those whom we identify as poor or welfare-reliant; (7) challenge the very idea that there is an American welfare state, proposing instead that there are and have been multiple intercutting American welfare states; (8) expand the roster of institutions we consider within the legitimate purview of what we call welfare state analysis; (9) help us reconceive how we measure welfare state success; and (10) reframe public policy debate. I'll take each briefly in turn.

\section{National Policy Bias}

In most social welfare histories, the central government's provision of insurance, pension, health, and (sometimes) education programs occupies a privileged place over mere poor relief, charity, or mutual aid. Thus, the birth of the American welfare state is often identified as the Social Security Act of 1935. Here is one acute example, from a generally thoughtful history of New England poorhouses:

SOCIAL POLICY (SUCH AS IT WAS) BEFORE 1935: For three hundred years before the passage of the Social Security Act of 1935, which provided not only pensions for the aged but also unemployment insurance and some federal welfare programs, the choices of poor, disabled, elderly, and others in need were fairly bleak. With no modern social welfare, any hope of aid rested on the Elizabethan Poor Laws developed in England and taken lock, stock, and barrel into American law. Despite the myth of American prosperity, periodic depressions and unemployment, 
disasters such as fires and wars, injury, and ill health produced plenty of adversity in America before the Social Security Act. ${ }^{19}$

Note how neatly it divides all of American social welfare history into two starkly different periods, and the implication that there was not still "plenty of adversity" after 1935. I offer this example not because it is extreme, but because this is a common manner of framing American social welfare provision. The historical truth is much more complicated, of course, and there were many varieties of relief available to Americans before the New Deal. But even in more sophisticated forms, such narrow emphasis on national policy innovation and activity seems myopic. Why should national policy change matter quite so much in a federal system? Part of the America-as-welfare-state-laggard story compares the national policy action of the United States against the scope and timing of European polities, polities with more centralized, unified political systems. By design, the national government did little before the 1930s (war making, treaties, land grants to states for hospitals and colleges, veteran's pensions, and post offices constituted the bulk of its activities); and there are credible arguments that the pre-1937 Supreme Court was correct in identifying the New Deal's massive expansion of national power as explicitly (if perhaps not implicitly) unconstitutional.

To employ a metric whereby broad national action designed to mitigate the worst effects of the free market indicates the presence of a welfare state is nearly to guarantee that the United States will fall to the bottom of the list. Given the peculiar structure of the American system, researchers might more properly measure government activity by attending to states, counties, and municipalities, too: by having failed to do so systematically, we have produced a distorted welfare state narrative. Indeedand this is worth emphasizing-for the poor the American state has never been weak. Poor Americans felt its full force long before the nationalization of policy in the twentieth century, and for them the welfare state has been a presence (a positive and negative one) since before the Revolution. The nineteenth century was neither a "state of courts and parties" nor even a state of "courts, parties, and corporations." 20 Since before the founding, and after, the state for poor Americans has been powerful and intrusive.

\section{Overemphasis of Public Programs}

We might also ask if we are well served by an understanding of the welfare state that privileges programmatic expenditures over tax expenditures, 
and, more generally, the public over the private. While there has been serious effort, notably from both Christopher Howard and Jacob Hacker, to persuade us to expand our traditional understanding of what might be included within the welfare state beyond public programs (given our distinct historical dependence upon private institutions), it is still public endeavor that has been the touchstone for identifying welfare state activity. ${ }^{21}$ But if one of the distinct features of American political history has been the involvement and power of nongovernmental institutions, by what logic do we begin by excluding them from our understanding of what constitutes welfare state activity?

This narrowness might also give way if researchers can shift analysis away from policy (policy outputs) toward a richer examination of its felt effects (policy outcomes), and their relationship to those other resources poor Americans have depended on. Government-produced policy is one among many independent variables, which must include the full panoply of means by which marginalized Americans seek to survive and thrive. It matters little to one in need of assistance where that assistance comes from or how it is financed; yet this is one way we have structured the grand narrative of the American welfare state and how we have been taught to think of its development-from local, private interventions to state and then federal public ones. These are and have been useful categories of analysis that have engendered much productive scholarship, and it is instructive to compare American public welfare effort with the public effort of other nations in order to highlight the very different kinds of states that have evolved. And the institutional location of policy matters, make no mistake. But these are less useful first distinctions in the kind of welfare state history I am arguing for. Municipal relief, state aid, and federal assistance; private charity; family support and assistance from friends, neighbors, and local merchants; work or work in the "informal" economy: for poor people these are often undistinguishable pieces of a large, ever-shifting, and complex puzzle that one must solve over and again to survive. The intricate web of dependencies Americans have acquired to get by does not respect the neat boundaries prescribed by historians and social scientists.

Now, it is true that one form of aid may bring with it a stigma not associated with another form, which may make private aid preferable to public, but even here we see potential for the familiar narrative to be upended. Perhaps, contrary to conventional historical wisdom, aid available in the nineteenth century was better than post-New Deal assistance because the assistance offered by fraternal organizations, for example, brought with it little shame. Or we might argue that since much 
early public relief came not from government directly, but from the political party, this afforded applicants some power in the relationship, since they had something to offer-their vote-in exchange for some clothes, a box of food or coal, or even a job, the most coveted prize of all. By contrast, when dealing with the Overseer, or, later, the social worker, an applicant had little power indeed, and was made a supplicant, forced by the state into a subordinate, passive role. From the perspective of the person in need, who was better off? In this light, have we made progress? What kind of institution or where it is located in the structure of the political system may not matter as much as (a) the sufficiency of aid relative to the need for it, (b) its reliability and duration, and (b) the ease with which it is accessed.

\section{Distorted Historical Landmarks}

It is not just the distinctions between public and private and federal, state, and local and the manner in which we evaluate welfare state activity and effectiveness that might recede in importance if we focus our attention more narrowly upon evaluating policy change from the perspective of the targets of relief policy. Such a shifting of our lens can also lead us to consider setting aside the turning points that feature so prominently in traditional American welfare state history.

To take only the most obvious example: the central moment of the traditional narrative for social welfare historians, of course, has been the New Deal. But there was little that was programmatically novel or innovative there: since at least the early nineteenth century, neighborhoods, fraternal organizations, and cities and towns have developed and implemented unemployment insurance, work relief, widow's benefits, and health-care programs, which were later built upon by states in the late nineteenth and early twentieth century. New Deal programs were not innovations. Moreover, those earlier experiments in offering help, like many work-relief programs and parish pension lists for the old and infirm, were rarely designed and implemented by the reform-minded politicians and philanthropists who take the lead in most histories, but more often were conceived, enacted, and administered by the poor unemployed themselves. It took a century or more for national elites finally to accept and adopt the solutions created first by poor and working people (private and municipal "wood token" and "potato ticket" programs anticipated food stamps by more than two hundred years, for example). What was novel with the New Deal was that the federal government began doing what private organizations and local and state governments 
had been doing since the founding and before. And, while some accounts have found the roots of New Deal programs in Progressive Era programs (which is true, so far as it goes), elite reformers still take center stage.

Further, while the passage of the Old Age Insurance provisions of the Social Security Act of 1935 might be the key turning point from a federalism or policy-innovation perspective, it did nothing for those in need in 1935. Or 1936. Or 1937. Only when seventy-six-year-old Ida Fuller received the first Social Security check on January 17, 1940, did the program begin to have an impact on Americans in need, and for most Americans it remained a mere abstraction until the 1939 Amendments (which created survivors' benefits) and the 1950 Amendments (which expanded eligibility for the program and increased the value of benefits). Only then did more Americans receive aid from Social Security than from old-age assistance, as Ed Berkowitz has shown. ${ }^{22}$ If we are concerned with policy change, 1935 is indeed a landmark, but if we are concerned with identifying points at which the relationship between Americans and the state changed in practical, tangible ways, the historical marker might then be better placed at 1950-or 1954, when benefits were some 85 percent higher than even in 1950, as Robert Lieberman has demonstrated. ${ }^{23}$ Our traditional focus has perhaps led us to misidentify a key moment of welfare state expansion by fifteen or twenty years.

\section{Bringing the Poor Back In}

In too many histories of the welfare state, what poor people do is suffer, sometimes quite nobly, and almost always passively. They are then rescued by benevolent reformers or kind-hearted (or self-interested) politicians. Rarely, however, have histories shown the role poor and unemployed Americans have had in creating policy or shaping their future. Yet the poor have made much policy, and might be given credit for it. Similarly, charity has not merely been the province of the benevolent rich and middle classes: just as today the poor and working classes tend to give a larger share of their incomes to others, so too in the past. One even more glaring omission in our stories of relief has been the fact that the poor have usually not asked for it. When desperate Americans have made demands of their government, it is work that they have typically asked for, only to be met with, when granted anything at all, paltry and demeaning aid, just enough to keep some families together and alive, never enough to thrive. Indeed, throughout our history many, faced with the choice between the shame of relief or nothing, have chosen nothing. 
Looked at this way, the American welfare state has rarely granted and never sustained what most poor Americans have demanded-a secure job at a decent wage. This highlights how few histories have examined relief programs from the perspective of those who have depended upon them, and how seldom their voices find their way into scholarship on the subject.

\section{Telling the Story of Stasis}

The usual narratives about how welfare policies have evolved over time may also be off the mark, for what is most striking, especially about poor relief, ${ }^{24}$ is how little it has changed over the course of American history. It is not, from the perspective of the poorest Americans, a story of policy progress, but one of stasis, short-term fluctuations in policy and practice notwithstanding. So too when we attend to political culture, and attitudes about the poor and about poverty (and attitudes and ideas of the poor about the state and institutions of relief). Stasis and continuity is the story, interrupted by occasional, aberrant events and shifts in opinionwhich is one way we might understand the mid-twentieth century, as a momentary, modest shift away from elites' antistate, antiwelfare ethos. It is the "constants" of policy and practice that might be the key pattern, for as economist Stephen Ziliak has demonstrated, from the 1820s (if not before) to the present, the average duration of relief receipt, the real value of benefits, "migrations" from welfare to work, and poorhouse populations have actually changed little. ${ }^{25}$ It may be our lack of progress that is the more accurate story. And, when listening to the poorest men, women, and children tell their stories about poverty and relief from throughout our history, that constancy is thrown into sharp relief: it can, for example, be difficult to distinguish the experience of living in an eighteenth-century almshouse from living in a twenty-first-century homeless shelter. ${ }^{26}$ Over the long sweep of American history, the experience of being poor and seeking the help of government has perhaps changed less than we might like to think. The expansion of what we call the welfare state has, and contrary to received wisdom, reached the middle classes more than it has the poor, who remain ever more vulnerable to the effects of industrial, and now global, capitalism.

Progress is thus another theme that might give way. Most histories have been able to describe the development of the American welfare state as generally forward-moving because the scale and scope of government relief has inarguably grown, especially over the course of the twentieth century. But this alone is not necessarily a mark of progress. Researchers 
might better correlate changes in assistance with changes in need, since what matters from this revisionist perspective is not whether government (or the private or not-for-profit sectors) does more in absolute terms, but, as I have proposed above, how many are in need of aid, how many receive it, and how adequate that aid is. If massive economic growth coincides with massive new need, yet the growth in the welfare state does not match the new need, we have not made progress, although we may have significantly increased effort and expenditure. We have, for example, traditionally thought of the colonial poorhouse or the process of auctioning off the poor as backward and unenlightened policies (and they were), but if the pre-Revolutionary political economy created modest (relative) need, and if almost all in need received sufficient aid from the community (as most urban histories assert), a typical poor family might have been better off in colonial Philadelphia than in Philadelphia today, where in some neighborhoods the post-transfer poverty rate is likely to be significantly higher than in the former period. Growth in the welfare state remains an empirical question, but an unfamiliar kind of empiricism is required if we shift attention from the mere development and elaboration of the state itself and turn instead toward the more complicated task of gauging its actual effects upon those at the receiving end of its policies. ${ }^{27}$

\section{Life Course Analysis}

Histories of "the poor" have obscured a central truth: as Mark Robert Rank and Thomas Hirschl have shown in analyses based on the Panel Study of Income Dynamics (which has been accumulating longitudinal data on American families since 1968), welfare and poverty are not the province of a minority of Americans, much less an "underclass." Over the course of their adult lives, 60 percent of Americans will be poor at least once, and 65 percent will receive some form of means-tested assistance. And while we make much, and rightly so, of the advances that Social Security has brought us, over 40 percent of those between the ages of sixty and ninety will nonetheless be poor at least once. By age seventy-five, onethird of Americans will be very poor, with income at half the poverty line. Of those who by age seventy-five are poor at least once, for some 30 percent it is for five years or more; thus, this is not some measure of a very brief episode these data magnify beyond reason. For a majority, it is an event, and for nearly one-third, it is a durable condition. Poverty is not an anomaly confined to some marginal and marginalized population but is a constant feature of American life that will be experienced by a majority 
of Americans. Poverty in America is endemic. But still we underestimate the problem, for these are data about the entire population. The situation is much worse for particular groups of Americans. By age seventy-five, 91 percent of African Americans can expect to experience poverty; for people with less than a high school education, it is 75 percent. Over the course of their lives (to age seventy-five) some 53 percent of whites can expect a spell of poverty; but African Americans have already reached that percentage by age twenty-eight. And if you are black and female, you can be expected to be counted among the 98.8 percent of your peers who will be poor at least once in your life. Some 34 percent of all Americans will be poor before they reach the age of seventeen: we can expect one-third of our children to live in poverty at some point. If they are African American, the number is 70 percent. If they are raised by a single mother with less than a high school education, almost all-99.4 percent-will be poor. As it has been for most of our history, poverty is inscribed into the lives of most Americans; it is a part of our national experience. ${ }^{28}$

Similarly, welfare receipt is not an aberrant behavior confined to the undeserving poor simply unwilling to work for their keep, as contemporary

antiwelfare rhetoric would have it, but is also a widespread feature of American life. Over their entire lifespan (to age sixty-five), from 1967 to 1996 some 65 percent of all Americans used some form of means-tested assistance-programs you must be poor enough to qualify for (AFDC/TANF, food stamps, Medicaid, SSI, General Assistance). Most of us will be on welfare. And for some 40 percent, it will be for a total of five years or more. (But still, over their lifespan, of those 65 percent who will use welfare, only for 16 percent is it for five or more consecutive years.) Welfare, though widely relied upon by many Americans, is used as most people seem to think it should be-as an interim measure that allows them to find another job, care for a sick child or parent, escape an abusive relationship, or even care for themselves. Those experiences, and such data, have yet to be fully incorporated into our analyses. ${ }^{29}$

\section{Multiple Welfare States}

There is another story that may merit a more coherent telling-the variation across time, place, and person of the experience of need. We might go so far as to reject the very idea that there has ever been such a thing as the American Welfare State; rather, there have been multitudinous American Welfare States. As the discussion above suggests, the welfare state has been a markedly different experience for women, for blacks in the South, 
for veterans, for middle-class whites in the North, for men, for children. And it has been different for different women, for different children, and so on. This is not itself a novel proposition. Linda Gordon, to take one example, has proposed that we distinguish between "two streams" of American social welfare policy, one that has targeted men (unemployment insurance, Social Security), and another for women (AFDC). ${ }^{30}$ Others have emphasized the manner in which blacks and whites have experienced distinct welfare states. But I propose here something slightly different (because it distinguishes streams by their effects rather than intent, structure, or function), and bolder, suggesting that we might productively adopt a multiple-streams approach to social welfare policy, eventually creating a typology of American welfare state regimes that differ not only among groups but also over time. So might researchers trace the various welfare states in our history, charting their distinct character and trajectories while highlighting those moments or conditions under which they intersect.

\section{New Welfare State Institutions}

Movement toward such a new social welfare history also suggests that we consider a broadening of the traditional welfare state definition. There is an argument to be made that the institution of the state that the poor American (and especially the poor black man) is and has been most likely to encounter is the police force, and we might therefore incorporate the criminal justice system generally, and the prison more specifically, into our thinking about the welfare state. According to recent data, some 2 million families receive TANF benefits, 600,000 people inhabit a homeless shelter on any given night, some 100,000 annually reside in mental hospitals, 6 million receive SSI, and perhaps 600,000 children live within the foster-care system. Most will concede that these are institutions and programs legitimately within the purview of welfare state analysts.

At the same time, according to the U.S. Department of Justice, some 2.1 million are confined within American jails and prisons, and another 4.8 million remain under the surveillance of the state on probation or parole. These men (and in growing numbers, women) are disproportionately black and Hispanic, poor, less educated, and drug- or alcohol-addicted. Felons and ex-offenders inhabit their own sphere in the welfare state, typically denied eligibility for public housing, food stamps, or in some states licenses to be bus drivers or hairdressers. To comprehend the political economy of the ghetto, we might consider the manner in which mass incarceration of 
black men has removed potential fathers, partners, and wage-earners from their community-urban poverty today cannot be understood without incorporating the prison. This was as true in our past as it is now, when the punishment for poverty-codified in an array of antivagrancy and antitramping laws in the North as well as the black codes of the South-was debtor's prison, the work farm, or indentured servitude, just as jail or expulsion from the city is today punishment for loitering, begging, sleeping in public places, or other public displays of need. May not the case for continuity here too be stronger than the case for progress and change? And by what standard do we now exclude these institutions from our thinking about the welfare state? It has not always been so: the central relief-minded association of the late nineteenth century, for example, was the National Conference on Charities and Corrections, and until that period the prison and the poorhouse were often, literally, the same institution.

\section{New Standards for Evaluation}

Much of what is proposed above would have implications for how we measure and evaluate welfare state success. Perhaps we might push this even further. Being poor is generally conceived as lacking social or economic rights-adequate resources for food, shelter, health care, for physical well-being. But throughout American history, to be poor has also often meant to lack political rights, to be denied the ability to participate fully as a citizen: to vote, to appear on jury pools, or to attain public office. While surely these failings are not so pressing as the need for basic sustenance and protection from the elements or disease, we might add these other "comforts" to the panoply of circumstances that mark one as a member of the lower classes, especially given the manner in which the power of the state has been used to deny some the status and benefits afforded others. While most northern locales extended the franchise to all white men by the 1820 s, there still remained explicit pauper restrictions on the books in half the states by 1960, and even today the poor-by virtue of their disproportionate representation among convicted felons and felon disenfranchisement statutes-have less access to democratic participation than others. ${ }^{31}$ It may be that such matters are not properly within the purview of a welfare state history and not reasonable standards for evaluating welfare state success, but here too we might argue for why they should not be so included and not merely assume that they do not belong. As Ralph Dahrendorf wrote, perhaps "all men are equal before the law, but they are no longer equal after it." ${ }^{32}$ 
The link to these political rights is not peripheral to economic poverty, for access to the former might give one power to affect the latter. The connection between political and economic rights has sometimes been direct: as John Alexander has shown in his history of poverty in early Philadelphia, the post-Revolutionary War expansion of the franchise led to fierce assaults on relief programs, out of fear that the newly enfranchised poor would vote their narrow class interests and thereby disrupt the established order. ${ }^{33}$ While we have often conceptualized the welfare state as positive action of the state to improve the material conditions of its citizens, we might pay more attention to its other face-action that has the intent or the effect of reducing the social or political liberty of one group. We have often shown how state activity alleviates poverty, but we have too little attended systematically to how it creates and fosters it. The welfare state need not be conceived as necessarily progressive or positive, and the expansion of the state's ability to grant aid also grants government new powers of coercion and control. In 1940, Henry Hopper and his family, Jehovah's Witnesses, were cut off the relief rolls in St. Clair County, Illinois, for his refusal to salute the American flag. Neil Ruth Cox reported to a Senate subcommittee in 1973 that she was informed that "if we wanted to keep getting welfare, I'd have to have my tubes tied." Examples could be multiplied a thousandfold, for poor Americans have often been asked to surrender their independence, of action and of mind, in order to receive relief. ${ }^{34}$ This too might be more fully comprehended within examinations of welfare state activity, since material poverty may be attended by a lack of civil rights as well, and we might now abandon T. H. Marshall's Whiggish suggestion that political rights have historically advanced from civil rights, and that the extension of political rights tends to foster the development of social or economic rights: to be poor in America is and has been to possess fewer civil, political, and social rights, and to be more subject to the power of the state itself. ${ }^{35}$

In an effort to take this "bottom-up" approach seriously-to shift analysis from policy per se to the lived experience of the poor and marginalized, and to operationalize this as dependent variable, American researchers might profitably adopt former World Bank economist Amartya Sen's redefinition of poverty as lack of freedom, or capability deprivation, in which freedom is the "capacity of people to live the kinds of lives they value-and have reason to value." 36 This approach may be well suited to the project proposed here, since it would focus attention upon how well Americans have managed to survive and thrive, and how that has differed for different groups, in different places, at various times throughout our history. 
In comparative welfare state analyses, independence, as measured by the extent to which it permits citizens to survive apart from the labor market (decommodification) or their ability to establish autonomous households (defamililization), has been a useful heuristic. ${ }^{37}$ But decommodification fails to capture fully the fact that poor people historically have not sought to be independent of the labor market; and defamilialization elevates autonomy to the status of virtue, and leaves out those who choose dependence, who do not wish to be islands of self-sufficient men and women, who expect to live as part of a family or as a community. Sen's standard of freedom might thus be a better measure than independence. A starting point could be, ironically, the Declaration of Independence. If we agree with Gary Wills that the Declaration has effectively been written into the Constitution, ${ }^{38}$ Jefferson's categories might serve as legitimate criteria for new evaluations of American welfare state effectiveness. To wit, we might devise means to measure how well various Americans have secured a good life (assessed perhaps by rates of mortality and morbidity, access to health care, adequate nutrition, clean air and water, protection from the elements); liberty (freedom of movement, of association, from crime and from state oppression, of speech, to participate meaningfully in their governance, to access good education, to work freely with equal, adequate remuneration); and happiness (opportunities for pleasure and play, for leisure time). Scholars could thereby devise an Index of American Freedom in an effort to evaluate the well-being of Americans and to gauge what government and nongovernmental actors have done to foster or inhibit it, providing an empirical means toward richer evaluations of the experience of American poverty and relief-receipt.

\section{Reframe Policy Debate}

Beyond this proposed effort to shift the frame for policy analysis and evaluation, such a project might also be conceived as a modest political intervention, offering a narrative counter to the dominant one that vilifies the poor and the state programs that would help them. This is particularly critical given efforts to move beyond the 1996 repeal of AFDC to broader reforms targeting Social Security, Medicaid, and Medicare, as well as food stamps, Head Start, the school lunch program, and more. There are many reasons we might retell the Whiggish history of the welfare state in such a manner. One is to counter the ignorance of policymakers and the public regarding the reality of life on the margins of America. Through understandings of the experiences of those who 
have been the objects and the subjects of social policy (and those denied its protection), Americans might come away a little more reluctant to demonize the poor and the unemployed and more willing to acknowledge the virtues of a welfare state (and the stake they have in it), perhaps even more willing to defend it and improve its effectiveness and efficiency. As novelist Edith Wharton wrote in The House of Mirth, "affluence, unless stimulated by a keen imagination, forms but the vaguest notion of the practical strain of poverty." A new welfare state history might more fully reveal that practical strain, bringing the experience of poor and working men and women and their encounters with the power of the state more fully into policy research.

That said, such a defense should be undertaken with caution and some ambivalence, and must keep fully in mind not only the manner in which programs and policies that purportedly help poor and working people have instead sought to control and succeeded in controlling their behavior regarding marriage, reproduction, and work (not all dependence is good, just as not all independence is bad, and government power can be tyranny and a danger just as it can be a salve), but must also not ascribe virtue to the poor merely because they are in need. This would merely be a form of historical patronizing. Not all poor people are or have been heroic, nor is their behavior necessarily to be celebrated. There is no nobility in poverty. But the scales have been so tilted toward one end of this spectrum that we might seek to reclaim some bit of truth from the sophists who insist (because it benefits them) that shared sacrifice and collective efforts are harmful, that poverty is a natural state, that immorality is at the root of need.

We need a new history of the American welfare state. We can begin to shape a new narrative, a retelling of policy history that places poor individuals and families at the center of this often-told tale, giving pride of place to their voices and their experiences. Such a history might both complicate and concretize the abstraction that is "the poor," challenge the conventional definitions of the welfare state and how we measure its reach and evaluate its effects, and trace over space and time how Americans are affected by public policies, not by offering yet another canvass of official data, but by boring in on individual cases, charting from family to family, from group to group, from era to era, the manner in which the power of government has been felt. We might redefine and reexamine the "stateness" in the welfare state by gauging its impact on citizens-to view the state indirectly, by observing its outputs and their impact. Only by doing so, as Daniel Carpenter suggested, "can transformations in the relationship 
between state and society be properly analyzed." ${ }^{39}$ It is not sufficient to chart changes in effort by the state or in aggregate measure of well-being, for they obscure too much; we should seek out the means to measure and describe the lived experience of those in need and their encounters with the state and its surrogates. This preliminary effort at this reimagining has proposed that an ostensibly simple shift in dependent variable might begin to unsettle familiar narratives of social welfare policy and policy history and thereby create space for us to think in new ways about the American welfare state.

Yeshiva University

Notes

1. Walter Trattner, From Poor Law to Welfare State (New York, 1998); see also James Patterson, America's Struggle Against Poverty, 1900-1994 (Cambridge, Mass., 1994); Bruce S. Jansson, The Reluctant Welfare State (Belmont, Calif., 2001); Howard Jacob Karger and David Stoesz, American Social Welfare Policy (Boston, 2005).

2. Michael Katz, In the Shadow of the Poorhouse: A Social History of Welfare in America (New York, 1996).

3. Theda Skocpol, Protecting Soldiers and Mothers: The Political Origins of Social Policy in the United States (Cambridge, Mass., 1992); Richard Franklin Bensel, The Political Economy of American Industrialization, 1877-1900 (Cambridge, 2000).

4. Jacob S. Hacker and Paul Pierson, "Business Power and Social Policy: Employers and the Formation of the American Welfare State," Politics and Society 30, no. 2 (June 2002).

5. Ellen Reese, Backlash Against Welfare Mothers, Past and Present (Berkeley and Los Angeles, 2005); Stephen Pimpare, The New Victorians: Poverty, Politics, and Propaganda in Two Gilded Ages (New York, 2004).

6. Jill Quadagno, The Color of Welfare: How Racism Undermined the War on Poverty (New York, 1994); Robert C. Lieberman, Shifting the Color Line: Race and the American Welfare State (New York, 2001).

7. Sanford F. Schram, Words of Welfare: The Poverty of Social Science and the Social Science of Poverty (Minneapolis, 1995); Charles Noble, Welfare as We Knew It: A Political History of the American Welfare State (New York, 1997); R. Kent Weaver, Ending Welfare as We Know It (Washington, D.C., 2000).

8. Paul Starr, The Social Transformation of American Medicine (New York, 1982); Jacob S. Hacker, The Divided Welfare State (Cambridge, 2002); Colin Gordon, Dead on Arrival: The Politics of Health Care in Twentieth-Century America (Princeton, 2003); Jill Quadagno, One Nation Uninsured: Why the U.S. Has No National Health Insurance (New York, 2005).

9. Julian E. Zelizer, "Introduction: New Directions in Policy History," Journal of Policy History 17, no. 1 (2005): 4.

10. Frances Fox Piven and Richard and Cloward, Regulating the Poor: The Functions of Public Welfare (New York, 1993) and Poor People's Movements: Why They Succeed, How They Fail (New York, 1979).

11. Charles Murray, Losing Ground: American Social Policy, 1950-1980 (New York, 1994).

12. Kathryn Edin and Laura Lein, Making Ends Meet: How Single Mothers Survive Welfare and Low-Wage Work (New York, 1997); Katherine S. Newman, No Shame in My Game: The Working Poor in the Inner City (New York, 1999); Barbara Ehrenreich, Nickel and 
Dimed: On (Not) Getting By in America (New York, 2001); Joe Soss, Unwanted Claims: The Politics of Participation in the U.S. Welfare System (Ann Arbor, 2002).

13. W. T. Couch, ed., These Are Our Lives: As Told by the People and Written by Members of the Federal Writers' Project of the Works Progress Administration in North Carolina, Tennessee, and Georgia (New York, 1939 [1967]); Ann Banks, ed., First Person America (New York, 1980); Charles T. Davis and Henry Louis Gates Jr., eds., The Slave's Narrative (New York, 1985); Billy Smith, ed., Down and Out in Early America (University Park, Pa., 2004); Ruth Wallis Herndon, Unwelcome Americans: Living on the Margin in Early New England (Philadelphia, 2001).

14. In Smith, ed., Down and Out in Early America.

15. Paul Pierson in Pierson, ed., The New Politics of the Welfare State (New York, 2001), chap. 13.

16. Gøsta Esping-Andersen, The Three Worlds of Welfare Capitalism (Princeton, 1990).

17. Diane Sainsbury, Gender, Equality, and Welfare States (Cambridge, 1996); Julia S. O'Connor, Ann Shola Orloff, and Sheila Shaver, States, Markets, Families (Cambridge, 1999); Helga Maria Hernes, Welfare State and Woman Power: Essays in State Feminism (Oslo, 1987).

18. Jacob S. Hacker, "Bringing the Welfare State Back In," Journal of Policy History 17, no. 1 (2005) 2005), 7.

19. David Wagner, The Poorhouse: America's Forgotten Institution (Lanham, Md.,

20. Stephen Skowronek, Building a New American State: The Expansion of National Administrative Capacities, 1877-1920 (Cambridge, Mass., 1997); David C. Hammack, Making the Nonprofit Sector in the United States (Indianapolis, 2000).

21. Christopher Howard, The Hidden Welfare State (Princeton, 1999); Hacker, Divided Welfare State.

22. Edward D. Berkowitz, America's Welfare State from Roosevelt to Reagan (Baltimore, 1991).

23. Lieberman, Shifting the Color Line.

24. That is, cash or in-kind grants of food, clothing, or fuel to the most poor, as distinct from insurance or pension programs more widely distributed across classes.

25. Stephen T. Ziliak, "Some Tendencies of Social Welfare and the Problem of Interpretation," Cato Journal 21, no. 3 (Winter 2002).

26. See, for example, Wagner, The Poorhouse.

27. Thus the virtue of replacement-rate-based analyses of welfare-state retrenchment over percentage-of-GDP measures, and of measures of unemployment frequency (the number unemployed at any point during a year) over unemployment rates (the number unemployed at one time).

28. Mark Robert Rank, One Nation, Underprivileged: Why American Poverty Affects Us All (New York, 2004).

29. Ibid.

30. Linda Gordon, ed., Women, the State, and Welfare (Madison, 1990). I'll set aside here questions of whether these programs actually sort into gender-specific streams in the manner Gordon suggests.

31. Alexander Keyssar, The Right to Vote: The Contested History of Democracy in the United States (New York, 2000).

32. Cited in Kenneth L. Karst, Belonging to America: Equal Citizenship and the Constitution (New Haven, 1989).

33. John K. Alexander, Render Them Submissive: Responses to Poverty in Philadelphia, 1760-1800 (Amherst, 1980)

34. Piven and Cloward, Regulating the Poor; Katz, Shadow of the Poorhouse; Andrew J. Polsky, The Rise of the Bureaucratic State (Princeton, 1991); Linda Gordon, Pitied But Not Entitled (Cambridge, Mass., 1994).

35. T. H. Marshall, Citizenship and Social Class (London, 1987). 
36. Amartya Sen, Development as Freedom (New York, 2000).

37. Nancy Fraser and Linda Gordon, "A Genealogy of Dependency: Tracing a Keyword of the U.S. Welfare State," Signs 19, no. 2 (Winter 1994); Esping-Andersen, Three Worlds; Ann Shola Orloff, "Gender and the Welfare State," Annual Reviews in Sociology 22 (1996).

38. Garry Wills, Lincoln at Gettysburg (New York, 1992).

39. Daniel P. Carpenter, The Forging of Bureaucratic Autonomy: Reputations, Networks, and Policy Innovation in Executive Agencies, 1862-1928 (Princeton, 2001). 